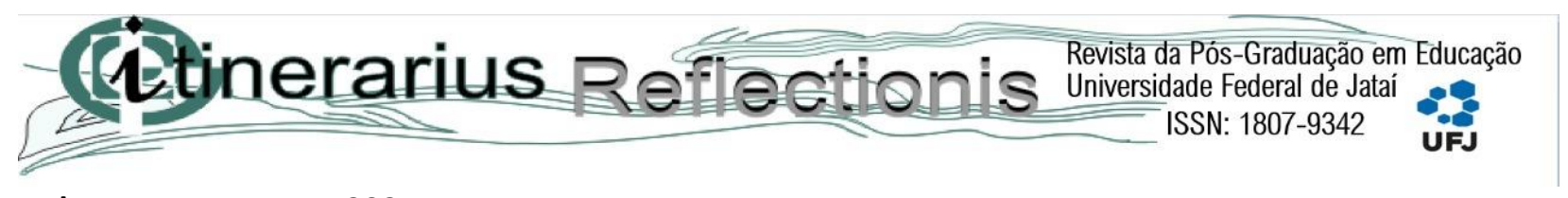

Volume 17, n. 4, ano, 2021

\title{
Onde tem fada... tem bruxa! Os desencantos dos livros de autoajuda para crianças
}

Sheila Daniela Medeiros dos $\operatorname{Santos}^{1}$

Resumo: Este trabalho objetiva desvendar os pressupostos ideológicos contidos nos livros de autoajuda para crianças, com base no referencial teórico de Vygotsky (1990), Lajolo (2005) e Zilberman (2003). Para concretizar este estudo realizou-se uma pesquisa bibliográfica e documental, e optou-se pelo recorte analítico dos livros de autoajuda para crianças que alcançaram um significativo volume de vendas entre os anos de 2014 a 2016 no Brasil. As análises do material revelaram que este gênero discursivo ao se sustentar nos pilares do ideário neoliberal e exaltar a política dos afetos, impõe o silenciamento e a submissão sob o disfarce da emancipação.

Palavras-chave: Livros de autoajuda. Crianças. Literatura.

\section{Where there is fairy... there is wich! The disenchantment of self-help books for children}

\begin{abstract}
This article aims to uncover the ideology subjacent in the self-help books for children, based on theoretical reference of authors as: Vygotsky (1990), Lajolo (2005) and Zilberman (2003). To conduct this study was carried a bibliographic and documental research and was performed an analytical clipping of the self-help books for children released by publishers which achieved a significant volume of sales from 2014 to 2016 in Brazil. The analyses of the selected material revealed that self-help books for children are based on the pillars of the neoliberal ideology. Therefore, this discursive genre exalts the politic of affections and imposes the silence and the submission, which are disguised as emancipation.
\end{abstract}

Keywords: Self-help books. Children,. Literature.

\section{INTRODUÇÃO}

O título inicial que designa este artigo faz alusão, embora de modo reverso, ao título do livro “Onde tem bruxa, tem fada...", de Bartolomeu Campos de Queirós, publicado pela primeira vez em 1979, pela Editora Moderna (QUEIRÓS, 2004).

Ao inverter a ordem dos termos bruxa e fada, como elemento proposital da estrutura semântica, procurou-se neste trabalho, por meio de um viés crítico, definir a temática a ser investigada, em razão da sedução, da magia e do aprisionamento que os livros de autoajuda têm

\footnotetext{
${ }^{1}$ Doutora em Educação (UNICAMP), Professora Associada (UFG). E-mail: sheiladmsantos@gmail.com
} 


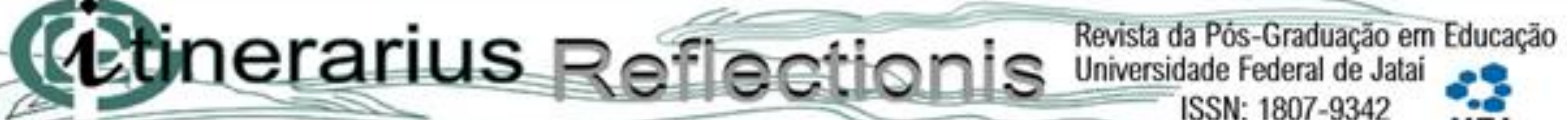 $\angle 20$}

Volume 17, n. 4, ano, 2021

suscitado na atualidade de modo subjacente, como se estivessem instituindo mudanças benéficas e inócuas no indivíduo.

Esta assertiva edifica-se em dados da realidade brasileira, em que é possível observar que o número de vendas dos livros de autoajuda alcançam proporções assustadoras. De acordo com o último relatório publicado pela Nielsen Bookscan Brasil (2015), empresa com experiência internacional que realiza análises do segmento livreiro, houve um aumento de $42 \%$ nas vendas desse gênero no país entre os anos de 2014 e 2015.

Nesta mesma direção, constata-se que os livros de autoajuda para crianças também estão se transformando em um fenômeno de interesse mercadológico, já que as editoras especializadas em obras infantis, pressionadas pela demanda, estão se dedicando à produção de selos editoriais prioritariamente destinados às crianças (ASSOCIAÇÃO NACIONAL DE LIVRARIAS, 2018).

Estes livros, produzidos a partir de um processo de massificação, disseminam-se sorrateiramente no contexto escolar, de tal forma que é possível ratificar a presença significativa de discursos enunciativos do gênero autoajuda nas relações que se instauram na cotidianidade educacional.

Embora existam pesquisas de autores, como: Asbahr e Ferreira (2002), Castellano (2015), Demo (2005), Romão (2009) e Souza (2011), que contribuem para a promoção de avanços aos debates que se instauram acerca da temática, observa-se que os estudos sobre os perigos da proliferação dos livros de autoajuda para crianças estão inscritos em um cenário teórico e analítico ainda tímido e de pouca visibilidade.

Diante desta preocupação, o presente trabalho objetivou desvendar os pressupostos ideológicos contidos nos livros de autoajuda para crianças, a partir do referencial teórico de autores como Vygotsky (1990), Lajolo (2005) e Zilberman (2003).

Ao considerar o eixo central deste estudo, assumiu-se como trajetória inicial mapear os pilares epistemológicos nos quais se edificaram a pesquisa e empreender as análises de alguns livros de autoajuda para crianças. Na sequência, buscou-se sublinhar a primazia da literatura infantil para o desenvolvimento da criança e para a constituição do sujeito leitor crítico. Para finalizar, o artigo procurou salientar que desvelar os pressupostos ideológicos implícitos nos livros de autoajuda para crianças é de fundamental relevância à escola, em particular, e à sociedade, em 


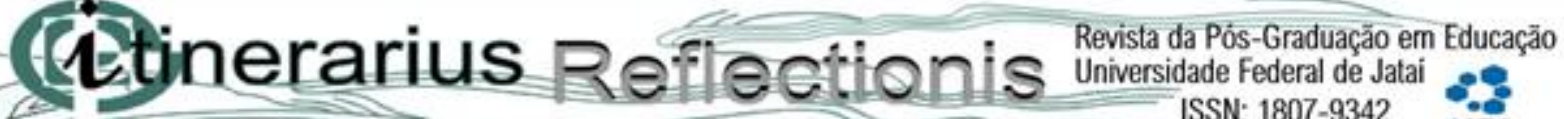 $\angle 2=$ \\ ISSN: $1807-9342$}

Volume 17, n. 4, ano, 2021

geral, pelo fato de fazer emergir mecanismos analíticos e interpretativos capazes de desnudar a ideologia neoliberal e as armadilhas dos discursos presentes neste gênero voltado às crianças.

\section{AUTOAJUDA PARA CRIANÇAS: LISURA OU SIMULACRO?}

No intuito de buscar uma explicação condizente com o objeto de investigação delineado iniciou-se uma pesquisa qualitativa (LÜDKE; ANDRÉ, 2013), de natureza bibliográfica e documental, e optou-se pelo recorte analítico dos livros de autoajuda para crianças que alcançaram um significativo volume de vendas no mercado editorial entre os anos de 2014 a 2016 no Brasil. No entanto, dados os limites de extensão deste artigo, buscou-se apresentar a análise detalhada de apenas três títulos.

Deste modo, selecionou-se os livros: “As coisas que eu amo em mim", de Trace Moroney (2013); "Faça seu mundo melhor", de Ruth Helena Oliveira de Souza e Roberta de Oliveira Ribeiro (2011); e "Quem mexeu no meu queijo? Para crianças", de Spencer Johnson (2009).

O primeiro livro analisado, “As coisas que eu amo em Mim”, de Trace Moroney, apresenta como propósito desenvolver nas crianças o amor-próprio, ou seja, conforme palavras da autora, a habilidade de identificar e lidar com os próprios sentimentos e virtudes na intenção de aumentar a autoconfiança e o pensamento positivo, com vistas a criação de uma base emocional saudável (MORONEY, 2013).

Segundo Moroney (2013), a criança, ao sentir-se bem consigo mesma, será capaz de aceitar melhor os outros e a si própria, libertando-se das limitações pessoais e criando uma sensação de calma e contentamento, a qual lhe permitirá abrir-se para receber amor das outras pessoas.

Em relação à produção visual, trata-se de um livro de capa dura, com o título centralizado na parte superior, que traz as palavras "amo" e "mim", com destaque em letra vermelha. Na capa há, também, diversos corações nas cores branco, rosa e vermelho - sendo este último em alto relevo confeccionado com um material aveludado -, e um coelhinho sorridente de braços abertos, pronto para acolher (ou capturar?) o leitor. Nota-se, portanto, que a capa do livro confeccionada pela equipe editorial dispõe harmoniosamente imagens e palavras vivazes, a fim de seduzir a criança.

Trace Moroney, conforme apresentação que figura ao final do livro, é "uma aclamada autora e ilustradora conhecida internacionalmente que já vendeu mais de 3 milhões de cópias de 


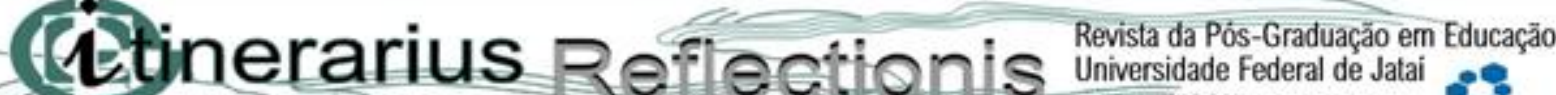

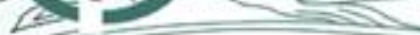

\section{Volume 17, n. 4, ano, 2021}

seus livros ao redor do mundo, os quais já foram traduzidos em mais de 15 idiomas" (MORONEY, 2013, não paginado). Dados os créditos atribuídos à autora pela editora, observa-se que as "notas para pais e cuidadores" descritas nas páginas finais do livro ganham relevância, uma vez que supõese vir de uma autora que possui propriedade para proferir breves aconselhamentos.

De acordo com a autora, o livro traz exemplos para a formação do pensamento positivo na criança em diferentes situações cotidianas. A autora alerta que, ao pensar positivamente, a pessoa não está deixando de ver a realidade e de reconhecer que acontecimentos ruins possam ocorrer, mas está apenas optando em centrar-se no otimismo, na esperança e nas oportunidades que podem surgir em diferentes situações (MORONEY, 2013). Neste sentido, a autora salienta:

\footnotetext{
Pesquisadores de psicologia positiva descobriram que pessoas com esse tipo de atitude são mais criativas, tolerantes, generosas, bem-sucedidas e abertas a novas ideias e experiências em relação às pessoas com atitudes negativas. Também são pessoas mais felizes, saudáveis, que vivem mais e estão mais satisfeitas com seus relacionamentos, além de terem grande capacidade de amar e se divertir (MORONEY, 2013, s/d).
}

Na sequência a autora salienta que o verbo "amar" aparece de forma recorrente no decorrer do livro, pelo fato de acreditar que a referida palavra, apesar de simples, é poderosa e deve ser usada para enfatizar o pensamento positivo das pessoas sobre os outros, as situações e as experiências que vivenciam.

Por esta razão, o coelhinho protagonista do livro faz afirmações do tipo: "Eu amo ser eu mesmo"; "Eu sou especialmente bom..."; e "Eu gosto mesmo de quem sou...". Além disso, o coelhinho anuncia enfaticamente ao final do livro: "eu espero continuar amando ser eu!", pois "ninguém no mundo inteiro é melhor em ser eu do que eu" e "eu amo ser quem eu sou" (MORONEY, 2013, não paginado).

Nesta perspectiva, a mensagem que a autora confere ao livro incita na criança uma espécie de narcísea social, uma vez que assim como no mito em que Narciso fixa seu sentido e não se deixa atravessar por outros discursos, preenchendo seu lugar de sujeito no mundo, sozinho (ORLANDI, 2007, p. 79), no livro “As coisas que eu amo em mim”, de Moroney (2013), a criança é enclausurada em um mundo onde não há movimento, mas há a exasperação de um só discurso.

Em outros termos, o livro procura privilegiar um 'eu', como se fosse possível ignorar a existência de muitos 'eus' da esfera pública que possibilitam a constituição do sujeito na esfera privada (PINO, 2005). Além disso, conforme observou Orlandi (2007), o sentido é errático e faz 


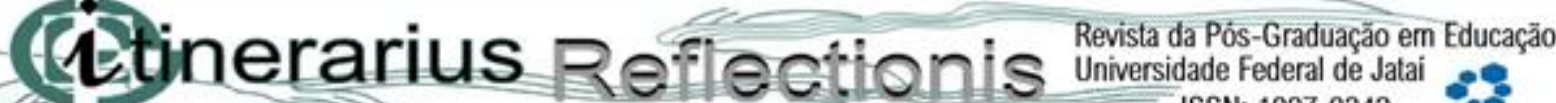 200

\section{Volume 17, n. 4, ano, 2021}

parte de suas condições de produção a circulação possível do sujeito pelas diferentes formações discursivas.

Deste modo, o livro, ao menosprezar determinados processos ímpares que fazem parte da condição humana - como a socialização das experiências, a premência do indivíduo se constituir na diferença e a vivência das relações que atravessam os movimentos coletivos -, promove o apagamento e o individualismo, no sentido de incitar a criança a dissuadir-se dos embates entre perspectivas distintas e contraditórias, de tal maneira a fomentar os mais coercitivos sentimentos narcísicos.

Outro livro analisado, intitulado "Quem mexeu no meu queijo? Para crianças", de Spencer Johnson (2009), retrata a estória de dois ratinhos e dois duendes - Sniff, Scurry, Hem e Haw, respectivamente -, os quais agem de modos distintos diante de um objetivo comum: encontrar um queijo mágico no interior de um labirinto.

O propósito do livro em questão é fazer uso de uma metáfora para indicar a possibilidade de mudança em um labirinto, o qual simboliza contextos diversos onde os quatro amiguinhos fazem uso de seu tempo para ir atrás de algo que almejam. O queijo é inserido na estória como uma alegoria para algo que as crianças desejam e perseguem, de tal forma que cada criança, ao ler o livro, delineará a ideia do que o queijo representa para si, acreditando que alcançá-lo a fará feliz.

Logo o queijo pode ser compreendido como um bem material que a criança deseja, como algo que envolve as relações que ela vivencia na escola, na família ou em outros espaços, ou ainda como algo relacionado à saúde, dentre outros aspectos. $\mathrm{O}$ fato é que, segundo o autor, se a criança obtiver o queijo, ficará ligada a ele, porém se o perdê-lo, ou se alguém o tirá-lo, este evento poderá ser traumático para ela.

Em relação ao design editorial da capa, pode-se afirmar que o mesmo é bastante atrativo. Trata-se de um livro de capa dura, em layout paisagem, com ilustrações grandes e paleta cromática com ênfase em cores como vermelho, laranja, amarelo, verde e azul, compostas por textos formatados em parágrafos de poucas linhas. No entanto, nota-se que não é apenas a estética da produção gráfica editorial que intenciona seduzir o leitor. O conteúdo de todo o livro contém armadilhas que procuram capturar o leitor.

$\mathrm{Na}$ contracapa do livro, o autor procura inquirir o leitor: "Como atravessamos o labirinto das mudanças?" Em seguida, destacando os nomes dos quatro protagonistas e a palavra “junto" em 
Volume 17, n. 4, ano, 2021

caixa alta, o autor escreve:

Às vezes agimos como SNIFF, que logo fareja a necessidade de mudança; ou SCURRY, que imediatamente entra em ação; ou HEM, que resiste às mudanças, pois está convencido de que elas são sempre para pior; ou HAW, que aprende a se adaptar quando percebe que as mudanças podem levar a algo melhor! Seja como for, todos nós temos uma características comum: a necessidade de encontrar nosso caminho no labirinto das mudanças. Mudar JUNTO com o queijo, esse é o segredo! (JOHNSON, 2009, não paginado).

Na página inicial do livro, o autor escreve uma nota aos pais, explicitando as razões que o levaram a escrever "Quem mexeu no meu queijo? Para crianças". Johnson (2009) menciona que milhões de leitores de seu best-seller "Quem mexeu no meu queijo?" - o qual vendeu mais de 20 milhões de exemplares em todo o mundo, sendo 1,5 milhão de cópias apenas no Brasil -, afirmaram que gostariam de ter conhecido a história narrada no livro durante a infância, pois desta forma teriam aprendido desde cedo a lidar com as mudanças, a fim de serem bem-sucedidos.

Na nota endereçada aos pais, Johnson (2009) conta que em certa ocasião sua família mudouse para um lugar muito distante, com uma cultura totalmente diferente daquela do qual fazia parte. Embora seus filhos tivessem se matriculado em outra escola, alguns meses depois do início das aulas "os professores ficaram encantados com a facilidade com que eles se adaptaram às circunstâncias" (JOHNSON, 2009, p. 7). Isso porque, enfatiza o autor, seus filhos cresceram ouvindo a história “Quem mexeu no meu queijo?” e já sabiam que as mudanças poderiam ser divertidas e levar a uma situação melhor (JOHNSON, 2009).

Por esta razão Johnson (2009) acreditava que a referida história, agora na versão infantil criada especialmente para as crianças, poderia ajudá-las "a mudar e a vencer!" (JOHNSON, 2009, p.7), principalmente se suas famílias estivessem passando por situações de mudança.

Ao final da nota, o autor dirige-se ao leitor, de modo imperativo: "Seja como for, esperamos... que muito em breve vocês todos encontrem seu próprio Novo Queijo - e sejam muito felizes!" (JOHNSON, 2009, p. 7).

É interessante notar que, no transcorrer do livro, o autor faz referência ao substantivo comum "queijo", como substantivo próprio, com a primeira letra da palavra em maiúscula, atribuindo-lhe destaque especial. Sem contar que há momentos em que o autor atribui demasiada ênfase à palavra que a apresenta completamente em caixa alta.

Com linguagem simples e leitura rápida, "Quem mexeu no meu queijo? Para crianças”, 


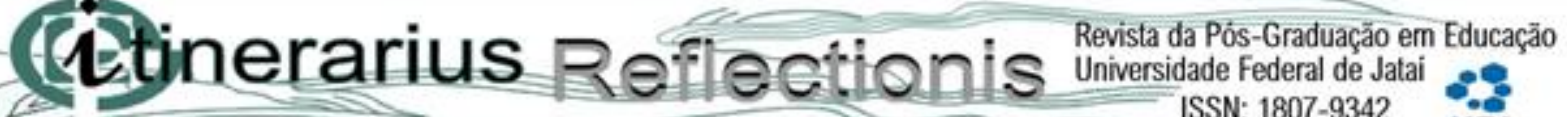 $\angle 20$}

Volume 17, n. 4, ano, 2021

afirma ter como propósito passar uma mensagem de motivação e sabedoria, a fim de "despertar" nas crianças, a percepção e o desejo de que é preciso estar aberto às mudanças e nunca se acomodar aos obstáculos que surgem na vida.

Á medida que o leitor avança nas páginas do livro se depara com dois ratinhos, Sniff e Scurry, e dois duendes, Hem e Haw, cuja tarefa é a de sair todas as manhãs em um labirinto à procura de um Queijo Mágico especial.

Os dois ratinhos, descreve o livro, são muito inteligentes e têm habilidades especiais para explorar lugares novos, um deles é um ótimo farejador e o outro excelente corredor. Já em relação aos duendes, o livro não faz uso do advérbio de intensidade para qualificá-los e apresenta-os apenas como inteligentes, destacando que ambos fazem uso de outros recursos para chegar ao Queijo Mágico: os dois leem livros e estudam mapas. Além disso, o autor trata o receio que Hem e Haw têm em relação ao fato de se perderem na escuridão do labirinto não como cautela, mas como falta de coragem.

O livro menospreza o conhecimento e exalta a intuição. Isso porque Haw e Hew, quem leem livros e estudam mapas, são não apenas menos inteligentes que os ratos, mas também mais lentos para notarem as mudanças. Hem opta em permanecer em um espaço conhecido e seguro, na esperança de que o queijo volte a aparecer. Haw, por sua vez, procura "adaptar-se" à mudança e é dele que saem as questionáveis conclusões do livro.

A estória narra que, em um "dia de sorte", em um lugar denominado Posto de Queijo Q, os quatro amiguinhos encontram uma grande quantidade de Queijo Mágico. $\mathrm{O}$ autor ressalta que o queijo "estivera ali o tempo todo, apenas esperando ser encontrado!" (JOHNSON, 2009, p. 16).

$\mathrm{Na}$ sequência, o autor relata que todos os protagonistas adaptam-se rapidamente à situação e vivem uma vida feliz mediante a descoberta feita, já que acreditam que têm queijo para uma vida inteira.

No entanto, como os quatro personagens saem todos os dias em direção ao Posto Q para comer queijo, "um belo dia", narra o autor, o queijo acaba. Porém, os dois ratinhos não ficam surpresos, por terem notado anteriormente que a quantidade de queijo estava diminuindo dia após dia. Neste momento o autor exalta novamente a inteligência dos ratinhos e atribui uma postura de conformismo aos duendes. Os duendes, por sua vez, ficam perplexos com o ocorrido, Haw fica desapontado e Hem, irritado, grita proferindo a seguinte frase: "O quê? Cadê o Queijo? Quem 
Volume 17, n. 4, ano, 2021

mexeu no meu Queijo" (JOHNSON, 2009, p. 28).

Por outro lado, segundo Johnson (2009), enquanto Sniff e Scurry decidem voltar ao labirinto para vasculhá-lo a procura de Queijo Novo, Hem e Haw, preferem retornar ao Posto de Queijo Q para esperar o queijo reaparecer. Até que Sniff e Scurry encontram, desta vez no Posto de Queijo N, uma quantidade ainda maior de Queijo Mágico. Diante deste fato, Haw decidi ir, sozinho, em busca de Queijo Mágico Novo, porque Hem sente medo e prefere continuar no Posto de Queijo Q.

O autor ressalta que Haw, em princípio, fica nervoso por não saber o que pode acontecer, mas depois se sente livre por estar vencendo o medo e percebendo que quanto mais rápido se abre mão do Queijo Velho, mais cedo se acha o Queijo Novo (JOHNSON, 2009). Por esta razão, Haw, à medida que percorre o labirinto, escreve ensinamentos em suas paredes, os quais são apresentados ao final do livro.

Em determinado momento, Haw volta ao Posto de Queijo Q onde estava Hem, não apenas para convencer o amigo a seguir-lhe na mesma jornada, como também para levar a ele pedacinhos de Queijos Novos que ele havia encontrado no caminho. Hem, por sua vez, recusa experimentar o Queijo Novo e, choramingando, prefere esperar que alguém lhe traga o Queijo Velho de volta.

O autor menciona que Haw fica triste e decepcionado, porém, o que causa estranhamento, é que mesmo assim ele decide abandonar o amigo e voltar ao labirinto para explorá-lo na certeza de encontrar Queijo Novo. Deste modo, nota-se, prioriza-se um bem material em detrimento às relações sociais, incluindo as afetivas estabelecidas entre os dois duendes. Portanto, a receita prescrita pelos fiéis ao Queijo é que o caminho certo é adaptar-se às mudanças, livrando-se ou simplesmente deixando para trás todos aqueles que resistem a elas.

Convém mencionar que, durante o trajeto, Haw repete afirmações próprias do pensamento positivo: "Eu estou feliz porque eu mudei. Porque estou fazendo algo novo. É divertido! Eu adoro este ‘novo’ Haw!” e “Imaginar seu queijo novo ajuda você a encontrá-lo!” (JOHNSON, 2009, p. 45).

Ao final do livro, para sintetizar a experiência de Haw adquirida no labirinto, há uma síntese do que o referido duende escreveu nas paredes ao longo de seu trajeto: 
Volume 17, n. 4, ano, 2021

Quando vencemos o medo, nos sentimos bem!

Quanto mais rápido abrimos mão do queijo velho, mais cedo achamos o Queijo Novo!

Imaginar seu Queijo Novo ajuda você a encontrá-lo!

Cheire o Queijo com frequência para saber quando ele está ficando velho.

Encontrar o Queijo Novo e aproveitar! (JOHNSON, 2009, p. 56-57).

Dentre as frases que Haw escreve nas paredes do labirinto, uma delas configura-se como peculiarmente intrigante: "Imaginar seu Queijo Novo ajuda você a encontrá-lo!" (JOHNSON, 2009, p. 57). Esta frase, indubitavelmente, insere a criança em um contexto em que os ecos discursivos proferidos pelos mestres da autoajuda, de que o pensamento positivo e/ou o poder da mente podem conduzir a materialização de algo desejado, são veementemente enfatizados.

De acordo com Seligman (2002), já há algum tempo, indivíduos acreditam que poderão mudar o modo como pensam sobre si próprios, tornando sua vida melhor, por meio do pensamento positivo e da repetição de afirmações positivas.

A premissa por trás do pensamento positivo, segundo Seligman (2011), é a de que o indivíduo, ao repetir declarações como "Eu sou uma pessoa forte" e "Eu posso atingir o sucesso", poderá mudar o modo como olha para si mesmo, levando a uma significativa alteração de comportamento capaz de produzir bem-estar pessoal e melhores resultados.

Entretanto, um estudo publicado no periódico Journal of Personality and Social Psychology, conduzido por pesquisadores das Universidades de Waterloo e de New Brunswick (WOOD et al. 2002), mostrou que indivíduos com autoestima baixa, sentiam-se pior em relação a si próprios depois de repetir sequencialmente afirmações típicas dos mantras positivos.

Este estudo concluiu que os indivíduos são mais suscetíveis em admitir ideias semelhantes ou ao menos próximas daquelas que já possuem e serem menos receptivos a modos de pensar distintos. Portanto, de acordo com o estudo, os indivíduos que sofrem de baixa autoestima geralmente rejeitam pensamentos contrários.

Cabe salientar, ainda, que na última página do livro: "Quem mexeu no meu Queijo? Para crianças", Johnson (2009) garante a quem encontrar o Queijo a obtenção de autorrealização, sucesso e felicidade.

Por fim, em essência, o aspecto insólito que a narrativa contida neste livro busca fomentar é a preeminência em adaptar-se às mudanças, nunca questioná-las e/ou enfrentá-las, além de que a lógica que impera é a meritocrática, em que a competição e o consumismo exacerbados predominam. Decorre desta afirmação que a criança é sugestionada a viver intensamente o 


\section{Volume 17, n. 4, ano, 2021}

presente, apartada do passado histórico, em que o mais importante é vencer, mesmo que o requisito para isso seja a racionalidade obscurantista e a opressão.

O último livro selecionado para análise, "Faça seu mundo melhor", de Ruth Helena Oliveira de Souza e de Roberta de Oliveira Ribeiro (2011), faz parte de uma espécie de kit que contém um livreto explicativo e vinte e cinco cartas ilustradas.

No livreto, após uma breve apresentação em que as autoras afirmam que para viver em um mundo melhor, onde haja amor, paz, harmonia, prosperidade e saúde para todos, é preciso anular as crenças negativas, neutralizando-as e construindo um caminho mental positivo, há menção explícita ao propósito do livro: "despertar a positividade na mente das crianças, dos jovens e até dos adultos, assim como a certeza de que cada um é um ser especial que nasceu para ser feliz" (FONSECA, 2011 apud SOUZA; RIBEIRO, 2011, p. 7).

$\mathrm{Na}$ sequência, o livreto explica os méritos das cartas contidas no kit, quais sejam: constituírem "um excelente instrumento de desenvolvimento mental e emocional, como também de reprogramação e eliminação de crenças negativas e bloqueios mentais" (FONSECA, 2011 apud SOUZA; RIBEIRO, 2011, p. 8).

As autoras reiteram que as cartas ajudarão as crianças a transformarem suas vidas em algo alegre e divertido, "por meio da repetição de afirmações e imaginações" que irão treiná-las a pensarem diferente e de modo agradável (SOUZA; RIBEIRO, 2011, p. 13).

De acordo com Souza e Ribeiro (2011, p. 18), as cartas funcionam da seguinte forma: quando as crianças pronunciam as afirmações contidas nas cartas em voz alta diversas vezes, elas começam a acreditar que a vida pode ser diferente, alegre e divertida. As autoras mencionam como exemplo o fato de uma criança não ter amigos e desejar muitas amizades. Neste caso, se a criança repetir uma das afirmações "Eu sou muito legal e todo mundo gosta de brincar comigo!!!" ou "Eu sou muito legal e todos gostam da minha companhia!!!”, a criança treinará a sua mente a aceitar que ela pode ser legal e ter diversos amigos.

Nas páginas seguintes o livreto apresenta orientações específicas para lê-lo e usá-lo e dá sugestões de como as crianças devem relacionar-se com as pessoas, adquirir autoestima e desvencilhar-se de sentimentos e pensamentos que consideram ruins. 


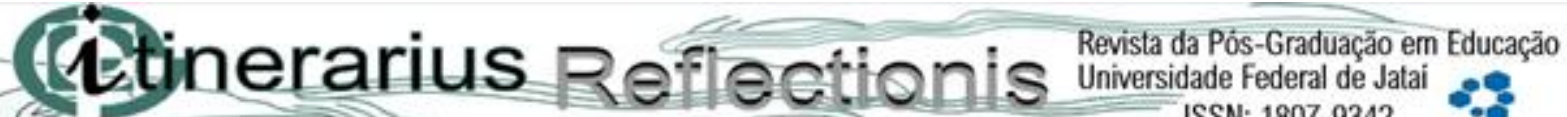 20}

Volume 17, n. 4, ano, 2021

Ao final do livreto, as autoras ressaltam que as cartas podem ser usadas com crianças de qualquer idade e, ao se dirigirem ao leitor em tom imperativo, finalizam: "Use você também as cartas!!!"” (SOUZA; RIBEIRO, 2011, p. 26).

As autoras explicam, ainda, que não importa a idade que se tem, pois as cartas funcionam com todas as pessoas, basta ter vontade de mudar. Para isso sugerem: "Permita-se fazer esta experiência e acredite nos resultados!!! Eles virão!!!” (SOUZA; RIBEIRO, 2011, p. 26).

Por último, há no livreto um desenho de uma criança sorrindo de braços abertos, onde se projeta apenas o rosto e os braços, em perspectiva, no interior de feixes de luz, em cores amarela e azul, com os dizeres: “Abra seu coração!!!” (SOUZA; RIBEIRO, 2011, p. 26).

O kit traz também duas cartas especiais que, segundo as autoras, podem ser usadas todos os dias e nas mais variadas situações. Estas cartas contém os enunciados: "Eu sou lindo(a), inteligente e bem-humorado(a)!!!"e "Tudo o que eu como e bebo me faz bem!!!"

Assim, o propósito do livro é incentivar a criança a escolher uma carta para um problema que ela tenha vivenciado ou esteja vivenciando. Há desenhos coloridos e sugestivos em uma das faces das cartas, sendo que no verso delas constam instruções distintas para cada problema apontado. Por exemplo, na carta intitulada "Eu só penso em coisas legais, alegres e divertidas!!!" está escrito:

Eu só penso em coisas legais, alegres e divertidas!!!

Usar quando:

Tiver pensamentos ruins;

Sentir-se mal por ter pensamentos estranhos ou ruins;

Imagens estranhas aparecerem na sua cabeça;

Tiver pensamentos de violência;

Sentir um peso ou uma pressão na cabeça;

Demorar muito para dormir à noite.

Ideia para a imaginação:

Imagine que um arco-íris desce direto na sua cabeça e que você sente uma sensação muito boa, como se fossem cócegas bem gostosas!!! Veja, na sua imaginação, a sua cabeça iluminada pelo arco-íris, com luzes coloridas saindo por todos os lados!!! Imagine isso muitas vezes.

Repita a afirmação em voz alta ou só no pensamento sempre que puder: antes de dormir e ao acordar, no banho, a caminho da escola...

É muito melhor do que ficar com medo de que algo ruim aconteça (SOUZA; RIBEIRO, 2011, p. não paginado).

Já na carta “Tá tudo bem comigo!!!!”, constam as seguintes construções discursivas: 
Volume 17, n. 4, ano, 2021

Tá tudo bem comigo!!!!

Usar quando:

Pensar que alguma coisa ruim vai acontecer com você;

Tiver qualquer sentimento ruim;

Acontecer algo na sua vida que te faça ficar triste;

Sentir saudade de alguém ou de um animal de estimação;

Sentir uma coisa ruim ou um aperto no peito;

Sentir-se em perigo ou com medo.

Ideia para a imaginação:

Imagine que você está caminhando bem confiante em um lugar com muita natureza, céu azul, nuvens branquinhas, sol brilhante, gramado verdinho, muitas árvores e flores!!! Imagine isso muitas vezes.

Repita a afirmação em voz alta ou só no pensamento sempre que puder: antes de dormir e ao acordar, no banho, a caminho da escola...

É muito melhor do que ter pensamentos e sentimentos ruins (SOUZA; RIBEIRO, 2011, não paginado).

Apesar de as autoras sustentarem que as crianças ao usarem as cartas estarão se desenvolvendo "de forma equilibrada, tranquila e amorosa, de bem consigo e com o mundo" (SOUZA; RIBEIRO, 2011, p. 25), ao analisar o conteúdo descrito nas referidas cartas, nota-se que as mesmas denotam uma realidade consubstanciada por ilusões e expectativas enganosas. A mais marcante e categórica delas está no fato de propor às crianças que a força do pensamento positivo lhe facultará poderes notáveis capazes de distanciá-las de acontecimentos ruins que lhe causam temor.

Deste modo, as crianças, ao imaginarem "que um arco-íris desce direto em suas cabeças, de tal forma que tenham uma sensação muito boa, como se fossem cócegas bem gostosas" (SOUZA; RIBEIRO, 2011, não paginado), e ao repetirem esta afirmação, muitas vezes, “em voz alta ou só no pensamento sempre que puderem: antes de dormir e ao acordar, no banho, a caminho da escola" (SOUZA; RIBEIRO, 2011, não paginado), são induzidas a acreditarem que poderão afastar os problemas mais complexos e angustiantes. Vale acrescentar que se a possibilidade de distanciar-se dos problemas por meio deste recurso já é questionável, enfrentar ou solucionar os problemas torna-se algo ainda mais impraticável nas referidas condições.

Além deste aspecto, faz-se necessário considerar outro ponto grave e preocupante: os casos de crianças que são vítimas de assédio sexual. Na maioria das vezes, estas crianças sentem-se culpadas, retraídas ou acuadas e a tendência é a de não revelarem verbalmente que estão vivenciando ou que vivenciaram situações de assédio. Isso porque, o indivíduo que pratica o assédio sexual contra crianças, para mantê-las em silêncio, pode chantageá-las, fazer ameaças ou 


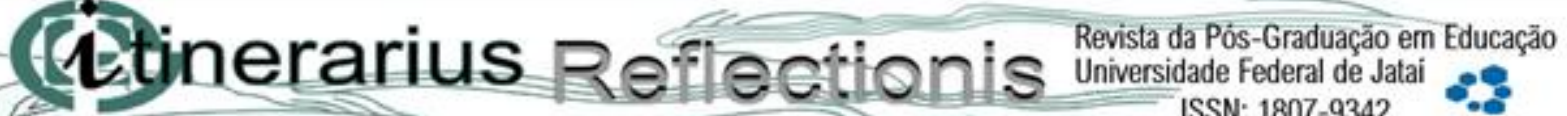 20}

\section{Volume 17, n. 4, ano, 2021}

até construírem uma relação de segredo com a vítima pautada na coerção e/ou no uso de benefícios materiais.

Por esta razão, é imprescindível que as crianças sejam conscientizadas e encorajadas a compartilharem quaisquer condição de assédio sexual que estejam experienciando ou tenham experienciado, para que possam ser acolhidas e o agressor ser responsabilizado.

Por último, após cotejar dados referentes ao material de análise da pesquisa, vestígios concretos mostraram que os livros de autoajuda para crianças, ao preconizar a força do pensamento positivo e os conselhos intangíveis, instilam uma notável postura autômata e uma busca incessante pela ilusória felicidade plena, contribuindo para conceber o simulacro e a concepção errônea de que em uma organização societária, onde a pobreza e as injustiças sociais são díspares, apenas não obtém sucesso e não é feliz aquele que não quer.

\section{DA PSEUDOLITERATURA À LITERATURA INFANTIL: NOTAS PARA UMA DISCUSSÃO CRÍTICA}

Os componentes essenciais do gênero autoajuda, edificados nos primórdios do século XXI, acenam para um modo de aliar os fundamentos do hedonismo às imposições do domínio Imperialista que, segundo Lenin (2011), legitimam processos de alienação e colocam em evidência particularidades e pormenores secundários, aprofundando as condições de pobreza e as desigualdades sociais.

Os livros de autoajuda geralmente dizem o que as pessoas querem ouvir (CASTELLANO, 2015). Ao prometerem poder e bens materiais, assim como conquistas na esfera afetiva, incitam posturas conformistas e alienantes, uma vez que disseminam a ideia de que a saída para os obstáculos e as adversidades da vida dizem respeito a uma questão unicamente individual, jamais coletiva.

O poderoso mote do gênero autoajuda é reclamar a função de determinar práticas que

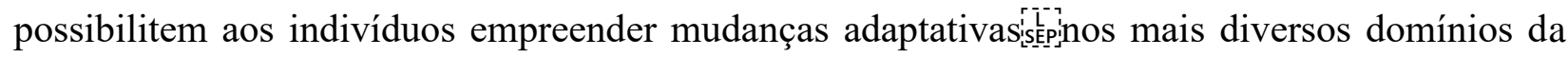
vida.

Apesar de o foco dos livros de autoajuda incidir constantemente sobre mudanças individuais, com base no suposto de que indivíduos em mudança possibilitam a construção de uma 


\section{Volume 17, n. 4, ano, 2021}

sociedade melhor, na realidade, estas mudanças estão totalmente alinhadas a um modelo de governamentalidade neoliberal (BAUMAN, 2017), com suas respectivas noções de autonomia e de independência, não apenas pelo fato de obliterarem aspectos sociais da vivência humana, mas também pelo fato de imporem modos específicos e padrões desejados de inserção dos indivíduos na sociedade.

De acordo com Siqueira (2017), o mundo atual denota a "era dos especialistas" em detectar problemas e clama por todo o tipo de assistência no que concerne a uma série de aspectos subjetivos - como se tornar assertivo, amável, confiante, seguro, popular, proativo; ou como se tornar menos tímido, inseguro, pessimista, ansioso e deprimido. Por outro lado, causa estranhamento o fato de que justamente a sociedade que enaltece a premissa "seja você mesmo", dita aos outros esse ideal por meio de receituários ou cartilhas de aconselhamento.

Uma leitura leviana deste movimento pode passar a impressão de que não há išẹpinada de novo no fato de um livro para crianças fazer uso da interpelações diretas. No entanto, uma análise minuciosa revela, a despeito de qualquer tentativa de naturalizar os processos sociais, a escalada do fenômeno da autoajuda e o viés de aconselhamento conectado com modelos de vida desejáveis.

De um modo geral, ao olhar atentamente para as construções linguísticas dos livros de autoajuda para crianças, observa-se um jogo instituído com frases de efeito e tautologias. Acrescenta-se a isso o fato de que a identidade visual das referidas publicações é projetada estrategicamente no intuito de relacionar-se de forma direta com um público específico, no caso, as crianças.

É possível constatar, pelo jogo retórico do discurso contido nos livros de autoajuda para crianças, que o autor apresenta-se como conselheiro, amigo, confidente e experiente no assunto pelo fato de, supostamente, ter experienciado situações análogas aos problemas vivenciados pelas crianças.

À luz das considerações esboçadas nota-se que, da mesma maneira que os livros de autoajuda para adultos (DEMO, 2005), os livros de autoajuda para as crianças intencionam cumprir uma função social em uma sociedade dividida em classes.

Estes livros, ao propiciarem uma orientação apressada e direta às crianças, outorgam espaço à tautologias, vocativos, ideias declináveis, promessas sedutoras, frases de efeito, opiniões frívolas, sugestões terapêuticas, visões utilitaristas do conhecimento, ausência de premissas fundamentadas, 


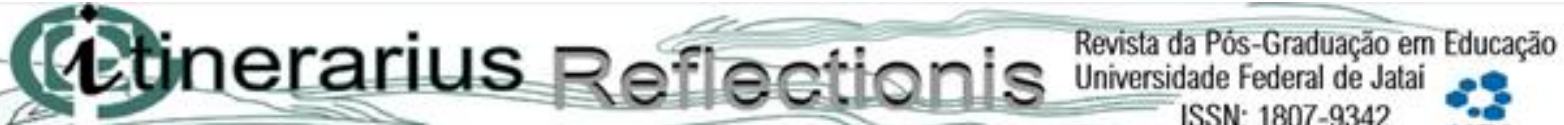 $\angle 20$}

Volume 17, n. 4, ano, 2021

enfim, tipologias pautadas em argumentos sem valor crítico e que são inerentes ao gênero autoajuda.

Se por um lado, os livros de autoajuda direcionados ao público adulto procuram enaltecer um modelo que alega satisfazer as necessidades de ordem material e espiritual, impondo determinados preceitos para romper paradigmas e para alçar brilhantismo profissional (ROMÃO, 2009), por outro lado, os livros de autoajuda para crianças se assentam com base em aspectos, como: ensinar a criança a enfrentar a separação dos pais; aceitar e superar a morte de entes queridos ou de animais de estimação; obter a preferência dos colegas, assim como boas notas na escola; e, ainda, indicar formas de como conformar-se com certas características físicas quando estas não condizem com os padrões impostos pela sociedade.

Neste ínterim, convém enfatizar, enquanto a retórica perfilhada pelos livros de autoajuda postulam-se convincentes, seduzindo (e alienando) o leitor, os livros de literatura para crianças, contrariamente, coadunam e negociam embates entre os posicionamentos divergentes, questionam temáticas universais, pactuam com a produção do conhecimento e tecem argumentos a respeito de variados gêneros de produções literárias (contos, mitos, poesias, teatros, fábulas, novelas, cordéis, entre outros), instigando posicionamentos críticos.

Lajolo e Zilberman (2007), em desafiantes estudos sobre este aspecto, asseveram que a literatura infantil faz uso de fantasias e metáforas para problematizar temáticas complexas, impelindo a produção imaginária e, por conseguinte, proporcionando ao leitor agir incisivamente na formação de uma consciência crítica e no processo de constituição identitária, de tal modo que lapsos decorrentes de experiências singulares se efetivem no processo dialógico em que se ancora a leitura.

Nesta perspectiva, Zilberman (2005) salienta que a literatura infantil é o lugar onde é possível transitar entre o paradoxal e o enigmático, na intenção de compreender e ressignificar o real com base na relação inextricável entre linguagem, imaginação, criatividade e fantasia.

De fato, segundo Vigotski (2001), a literatura infantil consubstancia-se como produto artístico, social, da ordem da cultura, capaz de conceber e medrar olhares peculiares e inéditos ao leitor, não somente no que diz respeito à experiência estética, mas também no que se refere ao campo da condição humana, da consciência concreta do homem e do processo de apropriação do universo cultural e simbólico que envolve a atividade imaginária. 


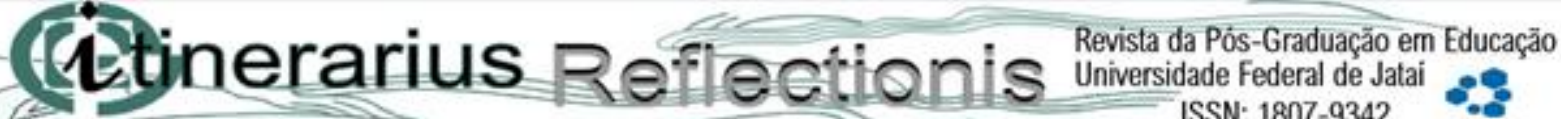 $\angle 20$}

Volume 17, n. 4, ano, 2021

Em relação a este debate, Abramovich (2006) ao realizar análises instigantes sobre a literatura infantil no espaço escolar, adverte para o fato de que as obras literárias, ao possuírem como cerne a ampliação do domínio cognitivo da criança, constituem um componente basilar ao serem usadas como instrumento mediador da cultura, como objeto estético e artístico, e, também, como recurso didático que cria experiências inovadoras e criativas.

Em face ao exposto, defende-se que a literatura infantil contribui para a formação da consciência crítica da criança ao proporcionar, além da apropriação do conhecimento, o desenvolvimento de uma visão política e histórica que movimenta a concretização da cidadania. Neste cenário, indubitavelmente, não há espaço para os livros de autoajuda direcionados às crianças em uma educação para a autonomia.

\section{CONSIDERAÇÕES FINAIS}

O presente trabalho objetivou desvendar os pressupostos ideológicos contidos nos livros de autoajuda para crianças. Durante o processo investigativo, as análises do material revelaram que os livros deste gênero consolidam um contexto enunciativo em que movimentos de aconselhamento focados no individualismo e na lógica da meritocracia, além de interpelações diretas e receitas aptas a dissimularem os problemas vivenciados pelas crianças, endossam o conformismo e a alienação em detrimento ao senso crítico.

As análises também evidenciaram que uma das estratégias utilizadas pelos livros de autoajuda para crianças é fazer uso de metáforas, quadros explicativos e recapitulações para tornar a leitura rápida e fácil, na intenção de fazer com que as crianças internalizem certos valores sociais relacionados aos desígnios de uma sociedade Imperialista.

A argumentação é direta, sólida e garante precisamente algo que a criança, em suas vivências complexas e singulares, deseja ler. Os livros de autoajuda para crianças prometem satisfazer ludicamente as necessidades das crianças e veicular o sucesso, propiciando pouca vazão para o estabelecimento de uma discussão crítica.

Por conseguinte, todas as peculiaridades que os livros de autoajuda para crianças preceituam, mediante dicas de comportamento que predizem a obtenção de segurança, felicidade e bem-estar, denotam quão obscuro é o movimento para desvelá-los. 
Volume 17, n. 4, ano, 2021

O ponto crucial destes aspectos permite contrapor as concepções de homem, de mundo, de infância e de educação que circulam na sociedade com aquelas que emergem de modo avassalador nos livros de autoajuda para crianças. Segue-se daí que estas concepções propaladas nos livros de autoajuda para crianças não condizem com a realidade com a qual nos deparamos na cotidianidade da dimensão social. Por este motivo, as receitas mágicas inverídicas disseminadas nos livros de autoajuda para crianças não funcionam.

Como um dos escopos dos livros de autoajuda é o de obstar a conquista da leitura como prática social, como forma de compreender a realidade e situar-se na vida social, é imprescindível mencionar no contex to deste estudo, conforme Lajolo (2010) bem observou, que a literatura infantil adquire importância capital no desenvolvimento da criança, em seus processos imagéticos e em sua atividade criadora.

A linguagem inventiva que marca os livros de literatura infantil centrados na estética e na ampliação do vocabulário, ao retratar determinada história, incontestavelmente, substitui a redundância e a imperatividade dos indizíveis vocábulos típicos dos livros de autoajuda: "faça", "tente" e "seja". Deste modo, a literatura pode ser uma poderosa ferramenta, uma vez que propicia a expressão de sentimentos, a revelação de experiências no domínio da linguagem, o redimensionamento dos significados e a negociação dos sentidos (VIGOTSKY, 2003).

Em relação a este aspecto convém reportar-se a Zilberman (2003), para quem a literatura é concebida como polissêmica, como jogo de palavras, não podendo ser confundida com textos moralistas ou manuais com excertos de aconselhamentos.

Além disso, segundo Vigotsky (2003), como a imaginação é constituída com base em elementos da realidade, os quais, por sua vez, são subordinados à atividade transformadora da produção imaginária, nota-se a intercorrência de uma relação de dupla dependência entre a imaginação e a experiência, uma vez que a experiência se assenta na imaginação e a imaginação se assenta na experiência.

Nesta circunstância, a criança, por meio da atividade criadora, pode revelar não apenas as produções fantasiosas, mas também os momentos de tensão e situações limítrofes, os quais vivencia na realidade.

Zamboni e Fonseca (2010) ampliam esta discussão ao acenarem para o fato de que a literatura, em sua relação com a história e a memória, expande o sentido das palavras, ressignifica 
Volume 17, n. 4, ano, 2021

os conceitos e os valores e impulsiona a imaginação para outras realidades, contextos e temporalidades, de tal forma a (re)construir outros modos de perceber o cotidiano, a história e os processos identitários.

Neste sentido, não é desmesurado reiterar, ao ancorar-se nas preleções teóricas de Vigotski (2001), que a literatura infantil é um modo de desnudamento da realidade e da expansão de referências culturais, cruciais para uma práxis pedagógica que tenha como escopo propiciar condições para que se efetive a relação entre a apropriação dos signos da cultura e o desenvolvimento psicológico da criança, recalcitrando o utilitarismo tácito que legitima o uso pérfido de livros de autoajuda para crianças no campo da educação escolar.

Convém enfatizar, ainda, que o contexto escolar constitui o locus primordial em que se instaura a práxis pedagógica, na acepção de Saviani (2005), e a apropriação da leitura como recurso indispensável para a aquisição da consciência crítica e para o exercício da cidadania na luta pelo concretização dos direitos sociais, contribuindo com o movimento de legitimação da literatura e da produção escrita em uma sociedade letrada.

Segundo Saviani (2005), a práxis pedagógica envolve uma relação inextricável entre teoria e prática, consubstanciada pela consciência filosófica, a qual conduz a uma ação revolucionária e transformadora.

No que tange a esta discussão, se a escola almeja a constituição de um leitor crítico, há a possibilidade de o professor, no ato de mediação, promover o acesso da criança às obras literárias, potencializando a imaginação, a criatividade e a objetivação das funções psicológicas superiores a serem desenvolvidas (VYGOTSKI, 1998).

Deste modo, torna-se essencial considerar, no contexto escolar, não apenas os paradoxos e as contradições históricas atinentes à produção e à sistematização do conhecimento científico, mas também o viés sedutor que o conteúdo do gênero autoajuda institui, a fim de que o leitor não seja aprisionado pelas devastadoras e causticantes armadilhas do pseudoconhecimento.

\section{REFERÊNCIAS}

ABRAMOVICH, F. Literatura infantil: gostosuras e bobices. São Paulo: Scipione, 2006. 
Volume 17, n. 4, ano, 2021

ASBAHR, M. C. C.; FERREIRA, N. S. A. Livros de auto-ajuda para crianças: uma coleção.

Revista Pro-posições, v. 13, n. 37, p. 186-199, 2002.

ASSOCIAÇÃO NACIONAL DE LIVRARIAS. Mercado de Livros. São Paulo, 23 jan. 2018.

Disponível em: http://anl.org.br/web/noticias/noticia_210.pdf. Acesso em: 24 nov. 2020.

BAUMAN, Z. O mal-estar na pós-modernidade. Rio de Janeiro: Jorge Zahar, 2017.

CASTELlANO, M. O sucesso é ser você mesmo: cultura terapêutica, autoestima e emoções na literatura de autoajuda. Revista Fronteiras/Estudos Midiáticos, v. 17, n. 3, p. 365-373, 2015.

DEMO, P. Autoajuda: uma sociologia da ingenuidade como condição humana. Petrópolis: Vozes, 2005.

JOHNSON, S. Quem mexeu no meu queijo? Para crianças. Rio de Janeiro: Record, 2009.

LAJOLO, M. P. No mundo da leitura para a leitura do mundo. São Paulo: Ática, 2005.

LAJOLO, M. P. Literatura infantil brasileira e estudos literários. Estudos de Literatura Brasileira Contemporânea, n. 36, p. 97-110, 2010.

LAJOLO, M. P; ZILBERMAN, R. Literatura infantil brasileira: histórias \& histórias. São Paulo: Ática, 2007.

LÜDKE, M; ANDRÉ, M. E. D. A. Pesquisa em Educação: abordagens qualitativas. São Paulo: EPU, 2013.

MORONEY, T. As coisas que eu amo em mim. São Paulo: Ciranda Cultural, 2013.

LENIN, V. I. O Imperialismo: etapa superior do capitalismo. Campinas: UNICAMP, 2011.

NIELSEN BOOKSCAN BRASIL. Número de venda dos exemplares de autoajuda cresce $42 \%$ em 2015. Insights. 23 out. 2015. Disponível em: http://www.nielsen.com/br/pt/insights/news/2015/Numero-de-venda-dos-exemplares-deautoajuda-cresce-42porcento-em-2015.html. Acesso em: 20 nov. 2020.

ORLANDI, E. P. As formas do silêncio: no movimento dos sentidos. Campinas, SP: Editora da Unicamp, 2007.

PINO, A. As marcas do humano. São Paulo: Cortez, 2005.

QUEIRÓS, B. C. Onde tem bruxa, tem fada. São Paulo: Moderna, 2004.

ROMÃO, A. M. Filosofia, educação e esclarecimento: os livros de auto-ajuda para educadores e o consumo de produtos semi-culturais. 2009. 167 f. Tese. (Doutorado em Educação) - Faculdade de Educação, Universidade Estadual de Campinas, Campinas - SP. 


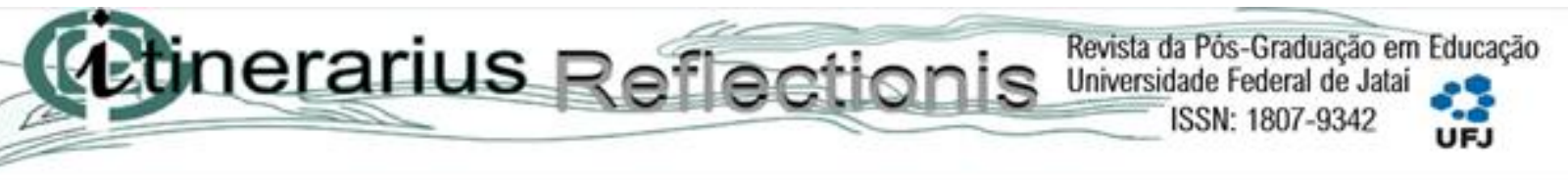

Volume 17, n. 4, ano, 2021

SAVIANI, D. Pedagogia Histórico-Crítica: primeiras aproximações. 9. ed. Campinas: Autores Associados, 2005.

SELIGMAN, M. E. P. Positive Psychology, Positive Prevention, and Positive Therapy. In: SNYDER, C. R. \& LOPEZ, S. J. (Eds.). Handbook of positive psychology. New York: Oxford University Press, 2002. p. 3-9.

SELIGMAN, M. E. P. Florescer: Uma nova compreensão sobre a natureza da felicidade e do bemestar. Rio de Janeiro: Objetiva, 2011.

SIQUEIRA, V. Livros de autoajuda e o consumo de conselhos - Modernidade e autoajuda. Colunas Tortas. 31 jan. 2017. Disponível em: https://colunastortas.com.br/livros-de-autoajuda/. Acesso em: 13 mar. 2021.

SOUZA, E. C. P. Mercadores de ilusões: a autoajuda e o empreendedorismo no cotidiano dos professores da rede pública do município do Rio de Janeiro. Rio de Janeiro: Quartet, 2011.

SOUZA, R. H. O. S.; RIBEIRO, R. O. Faça seu mundo melhor. São Paulo: Mundo Melhor, 2011. VIGOTSKI, L. S. Psicologia da arte. 2. ed. São Paulo: Martins Fontes, 2001.

VIGOTSKY, L. S. Imaginación y creación en la edad infantil. Buenos Aires: Nuestra América, 2003.

VYGOTSKI, L. S. Historia del desarollo de las funciones psíquicas superiores. Obras escogidas, 2. ed. Madri: Visor, 1998. Tomo III. p. 1-340.

VYGOTSKY, L. S. La imaginación y el arte en la infância. 2. ed. Madrid: Ediciones Akal, 1990. WOOD, J. V. et al. Do people with low self-esteem really want to feel better? Self-esteem differences in motivation to repair negative moods. Journal of Personality and Social Psychology, n. 82, p. 128-147, 2002.

ZAMBONI, E. ; FONSECA, S. G. Contribuições da literatura infantil para a aprendizagem de noções do tempo histórico: leituras e indagações. Caderno Cedes, v. 30, n. 32, p. 339-353, 2010. ZILBERMAN, R. A literatura infantil na escola. 11. ed. São Paulo: Global, 2003.

ZILBERMAN, R. Como e por que ler a literatura infantil brasileira. Rio de Janeiro: Objetiva, 2005. 